Egyptian Journal of Aquatic Biology \& Fisheries

Zoology Department, Faculty of Science,

Ain Shams University, Cairo, Egypt.

ISSN $1110-6131$

Vol. 23(5): 89- 105 (2019)

www.ejabf.journals.ekb.eg

\title{
Mesozooplankton in a stressed area of the Nile Delta Coast, Egypt.
}

\section{Mohamed Dorgham ${ }^{1 *}$, Wael El-Tohamy ${ }^{2}$, Jian Qin $^{3}$, Nagwa Abdel-Aziz ${ }^{4}$ and Ahmed El-Ghobashy ${ }^{2}$}

1- Oceanography Department, Faculty of Science, Alexandria University, Egypt.

2- Zoology Department, Faculty of Science, Damietta University, Egypt.

3- School of Biological Sciences, Flinders University, Adelaide SA, Australia.

4- National Institute of Oceanography and Fisheries, Alexandria, Egypt.

*Corresponding author: mdorgham1947@yahoo.com,

\section{ARTICLE INFO}

\section{Article History:}

Received: Nov. 22, 2019

Accepted: Nov. 28, 2019

Online: Dec. 2019

\section{Keywords:}

Damietta coast

Mesozooplankton

holoplankton

Nile Delta

Terrestrial stress

Community structure

\section{ABSTRACT}

The mesozooplankton was studied biweekly for one year in a part of the Nile Delta coast laying under the stress of different human activities. The study recorded 59 species amounted totally to an average of $59.7 \times 10^{3}$ $\operatorname{orgm} / \mathrm{m}^{3}$. Copepods were the highest diverse group (25 species), constituting $86.4 \%$ of the total mesozooplankton count. The other holoplankton groups were poorly represented and collectively formed $5 \%$ in addition to $8.6 \%$ for meroplankton. The community structure and numerical abundance experienced pronounced spatial and temporal variations relative to the surrounding environmental conditions. The Shannon index and dominance index were low over the whole area, while the evenness index appeared high. Salinity seems to be the essential factor that controls the distribution of the different groups, but other environmental parameters were also encountered. The nauplii larvae of copepods were the major mesozooplankton component, while a few species displayed clear abundance and were responsible for the abundance of the adult forms.

\section{INTRODUCTION}

Zooplankton can be used as "bioindicators" for water pollution (Oliver, 1996), changes in marine ecosystems (Falcão et al. 2012), and the effect of human activities (Leonardo et al. 2009; Vadadi-Fülöp et al. 2009). This because they have substantial different structure (Havens and Hanazato, 1993; Gyllström et al. 2005), different life cycles (Jakhar, 2013), and they are of high susceptibility to the environmental changes (Neto et al. 2014). The plankton analysis helps in explaining the cause of color, turbidity, presence of odor, taste and visible particles in water (Vaidya, 2017).

During the past two decades, the zooplankton in the Egyptian Mediterranean waters has drawn great attention, particularly along the Alexandria coast (e.g. AbdelAziz, 2006; Abdel Aziz et al. 2006; Zakaria, 2006, 2007, 2014, 2015; Abou-Zaid et al. 2014; Aboul-Ezz et al., 2014a; Abo-Taleb, 2014; Heneash, 2015; Abo-Taleb et al. 2016). Some studies were done on other parts of the Egyptian Mediterranean Coast (e.g. Aboul Ezz et al. 2014b; Zakaria et al. 2016, 2018). The total zooplankton was also studied in different parts of the coastal waters off the Nile Delta (El-Tohamy, 2005, 2012, 2015; Abdel Aziz et al. 2007; Dorgham et al. 2009, 2013; El-Tohamy et al. 2012, 2017, 2018, 2019). All the previous studies were restricted to localised areas 
or concerned with certain groups, and based mainly on seasonal samples. The present study was carried out at short time intervals, aiming to follow the biweekly structure and abundance of mesozooplankton community along a part of the Nile Delta coast relative to the surrounding environmental conditions for a complete year.

\section{MATERIALS AND METHODS}

\section{The area of study}

The concerned area extends along the Damietta coast on the south eastern Mediterranean Sea between $31^{\circ} 10$ and $32^{\circ} 05 \mathrm{E}$ and $31^{\circ} 20$ and $31^{\circ} 35 \mathrm{~N}$. This area is an important part of the Egyptian Mediterranean Coast, because it is directly affected by freshwater discharge from Damietta branch of the River Nile. It also receives different effluents of domestic, industrial, and agricultural wastes, and is influenced by fishing industry and fish farming in the surrounding land. The present study was carried out at five stations, representing different ecological entities (Fig. 1).

Station I: lies at the connection between Manzalah lagoon and the Mediterranean Sea, and is affected directly by the fresh water of Damietta Branch, domestic wastes, industrial wastes from a sardine factory, and wastes from fish ponds.

Station II is located at the connection between the Damietta Harbour and Mediterranean Sea, and is influenced by sewage and agricultural wastes, chemical fertilizers, and wastes from methanol production and liquefaction of natural gas.

Station III lies west to the River Nile Branch at Isbet Setta and receives great volume $\left(6 \times 10^{6} \mathrm{~m}^{3} /\right.$ day $)$ of untreated agricultural, industrial and sewage discharge from the City of New Damietta.

Station IV is located at the mouth of Gamsa Drain, which receives about $13.1 \times 10^{6} \mathrm{~m}^{3}$ /day of untreated sewage and agricultural waste waters from the Talkha fertilizers factory.

Station V lies at the mouth of El-Kasara Drain, receiving approximately $8.6 \times 10^{6} \mathrm{~m}^{3}$ /day of industrial, agricultural, and sewage wastes, in addition to the waste water of the surrounding fish ponds.

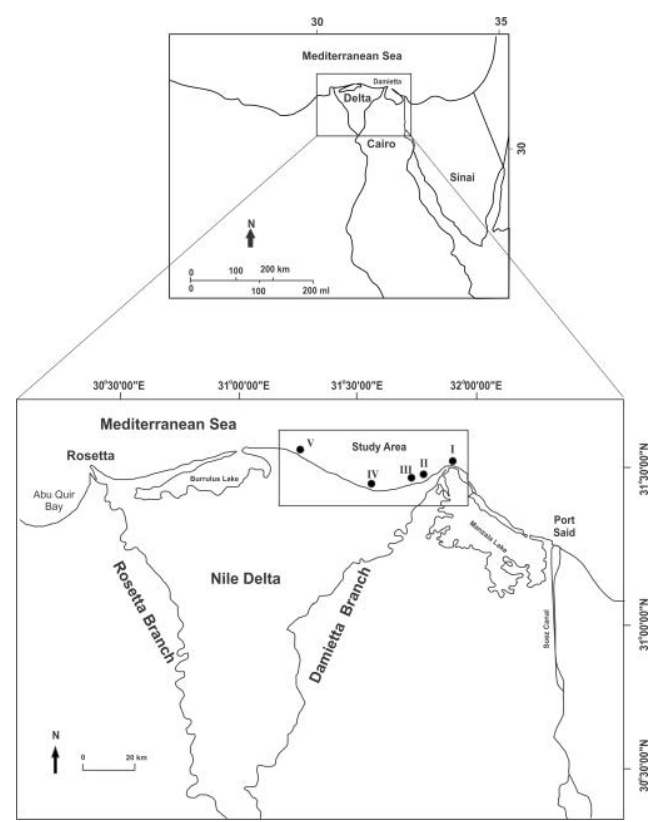

Fig.1: Map of the study area showing the positions of the sampling stations. 


\section{Zooplankton collection}

Zooplankton samples were collected by filtering 100 litres of seawater through a plankton net of $55 \mu \mathrm{m}$ mesh size. The filtered samples were concentrated to $100 \mathrm{ml}$ volume and preserved in 5\% neutralized formalin solution. The mesozooplankton was identified mostly to species level, following the known taxonomic references. The standing crop was estimated from the mean count of three sub samples of $5 \mathrm{ml}$ and expressed as organisms $/ \mathrm{m}^{3}$.

\section{Diversity Indices:}

The zooplankton diversity was assessed by calculation of some indices, like Shannon Diversity index, Evenness index, and Dominance index, following Hossain et al. (2017).

\section{Statistical analysis}

ANOVA and Correlations were performed using SPSS 18. The spatial environmental status of the five sampling stations was summarized using Principle Component Analysis (PCA) ordination. Canonical Correspondence Analysis (CCA) was performed to assess the association of zooplankton species with environmental factors. A Monte Carlo test was used to evaluate the significance of canonical axes and the environmental variables by using 999 unrestricted permutations (Sousa et al. 2008).Software package CANOCO version 4.5 was used for both PCA and CCA analyses.

\section{RESULTS}

\section{Physical chemical parameters:}

The environmental parameters of the concerned area were measured concurrently with the data of the present study (Dorgham et al. 2019). As shown in Table 1, the area of the present study comprised water masses with pronouncedly different environmental characteristics which would influence the structure and abundance of mesozooplankton.

Table 1: Hydrographic conditions and nutrients along the study area (After Dorgham et al. 2019)

\begin{tabular}{llllll}
\hline & Site I & Site II & Site III & Site IV & Site V \\
\hline Temp. & $22.1 \pm 5.26$ & $22.17 \pm 5.14$ & $22.17 \pm 5.17$ & $22.3 \pm 5.1$ & $22.27 \pm 5.29$ \\
Salinity ( \%o) & $25.03 \pm 6.26$ & $16.43 \pm 9.61$ & $18.55 \pm 7.58$ & $1.37 \pm 1.86$ & $4.02 \pm 1.02$ \\
pH & $7.9 \pm 0.16$ & $7.98 \pm 0.2$ & $7.73 \pm 0.2$ & $7.59 \pm 0.21$ & $7.74 \pm 0.2$ \\
DO & $6.37 \pm 1.5$ & $7.35 \pm 2.07$ & $5.56 \pm 1.94$ & $2.63 \pm 1.77$ & $4.42 \pm 3.15$ \\
Turbidity & $18.59 \pm 24.84$ & $3.86 \pm 3.49$ & $44.84 \pm 36.02$ & $34.65 \pm 11.89$ & $32.32 \pm 10.61$ \\
Silicate & $52.28 \pm 68.52$ & $39.66 \pm 25.47$ & $106.3 \pm 90.08$ & $149.26 \pm 66.96$ & $255.84 \pm 80.18$ \\
Nitrate $(\mu \mathrm{M} / \mathrm{L})$ & $0.42 \pm 0.36$ & $0.83 \pm 0.74$ & $1.08 \pm 0.81$ & $9.71 \pm 5.61$ & $3.42 \pm 2.76$ \\
Nitrite $(\mu \mathrm{M} / \mathrm{L})$ & $0.24 \pm 0.24$ & $0.57 \pm 0.69$ & $0.76 \pm 0.66$ & $7.46 \pm 4.99$ & $2.63 \pm 2.40$ \\
Ammonia & $0.27 \pm 0.36$ & $1.07 \pm 1.32$ & $4.27 \pm 3.63$ & $31.14 \pm 21.99$ & $4.05 \pm 3.29$ \\
Total phosphorus & $11.72 \pm 21.41$ & $14.45 \pm 25.48$ & $16.71 \pm 26.34$ & $14.96 \pm 22.51$ & $16.72 \pm 24.15$ \\
Chlorophyll a & $7.04 \pm 10.38$ & $12.55 \pm 9.67$ & $8.12 \pm 6.63$ & $8.77 \pm 4.29$ & $80.56 \pm 49.73$ \\
\hline
\end{tabular}

\section{Mesozooplankton diversity}

The present study identified 59 mesozooplankton species, with more diverse copepods, and less diverse cladocerans, nematodes, and cnidarians (Table 2). The high salinity stations (I, II, III) hosted 40-41 species, while the low salinity stations (IV and V) hosted 29 species (Fig. 2), displaying biweekly variation, with the highest number in spring and the lowest in autumn (Fig. 4).

The Shannon-Weaver index (H') reflected low diverse mesozooplankton in the area of study, attaining close annual average $(1.57,1.67,1.44,1.56$ and 1.87 respectively) at all the sampling stations (Fig. 3) and experienced temporal fluctuation at each station, with high values during winter and spring and clearly low value during autumn (Fig. 4). 
Table 2: The richness of mesozooplankton groups.

\begin{tabular}{lclc}
\hline Group & Sp.No. & Group & Sp.No. \\
\hline Cnidarian & 5 & Amphipods & 4 \\
Nematodes & 6 & Mysidacean & 2 \\
Pteropoda & 1 & Cumacean & 1 \\
Copepods & 25 & Chaetognaths & 1 \\
Cladocerans & 10 & Larvacean & 2 \\
Ostracods & 2 & Total & 59 \\
\hline
\end{tabular}

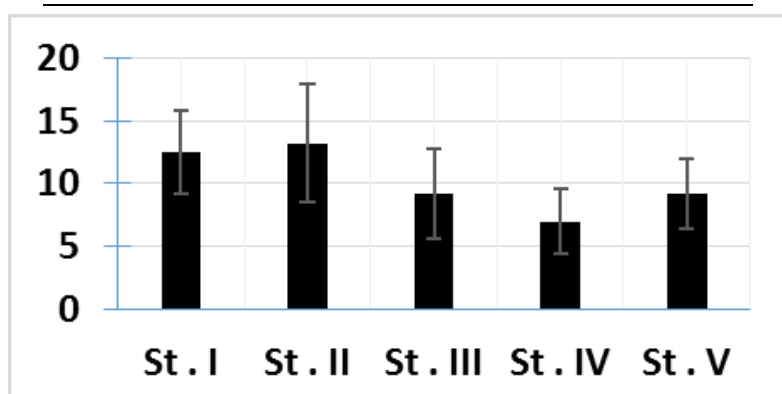

Fig. 2: Mean and standard deviation of species number of measozooplankton at the sampling stations.

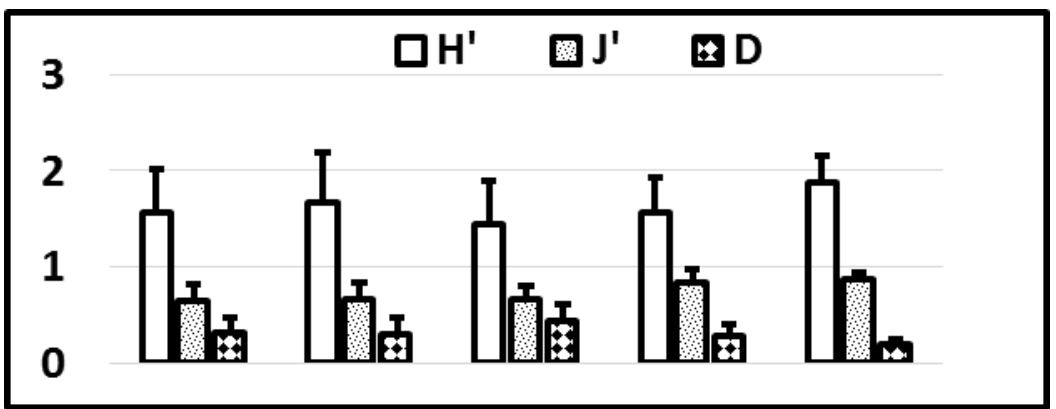

Fig. 3: Mean and standard deviation of diversity index $\left(H^{\prime}\right)$, evenness $\left(J^{\prime}\right)$ and dominance index (D) of mesozooplankton at the sampling stations.

The evenness index ( $\mathrm{J}$ ') was high and showed approximately similar patterns of spatial and temporal variations to those of diversity index, but with different ranges of variation. As sown in Figure 3, comparatively higher evenness was observed at the low salinity $(0.82-0.86)$ than those at the high salinity $(0.64-0.66)$, while in winter and spring it was higher than in summer and autumn (Fig. 4). The dominance index (D) was generally low, with annual mean fluctuated between 0.19 at station $\mathrm{V}$ and 0.43 at station III (Fig. 3), with high values during February, May and September, and relatively low values during most of the year (Fig. 4).
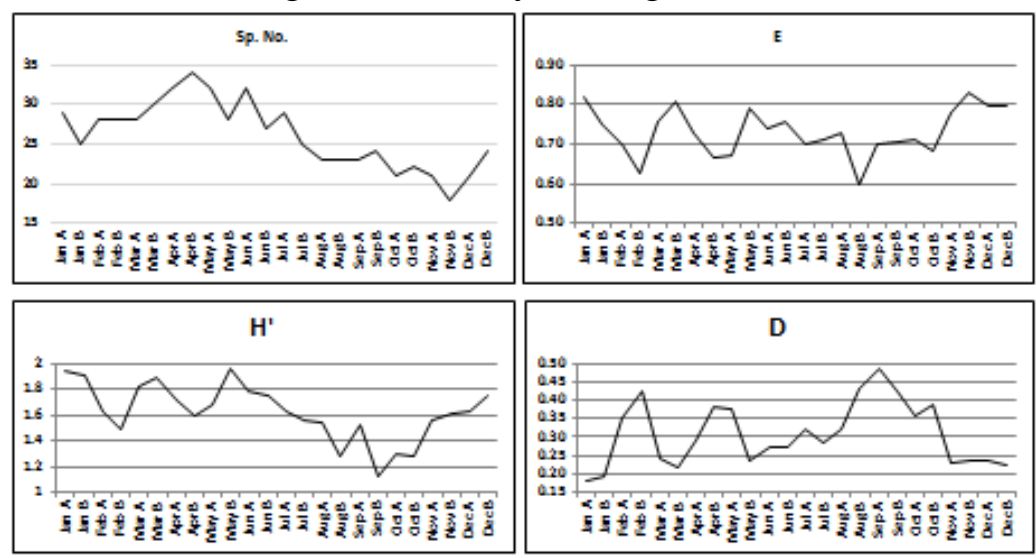

Fig. 4: Biweekly variation of diversity index $\left(\mathrm{H}^{\prime}\right)$, evenness index (E) and dominance index (D) of mesozooplankton at the sampling stations. 
The mesozooplankton count displayed great fluctuation over the area of study $\left(3.0 \times 10^{3}-631.3 \times 10^{3} \mathrm{orgm} / \mathrm{m}^{3}\right)$, attaining an annual average of $59.7 \times 10^{3} \mathrm{orgm} / \mathrm{m}^{3}$. Figure 5 illustrates that station II hosted the maximum count $\left(129.2 \times 10^{3} \mathrm{orgm} / \mathrm{m}^{3}\right)$ and station IV hosted the minimum count $\left(15.6 \times 10^{3} \mathrm{orgm} / \mathrm{m}^{3}\right)$. The biweekly abundance recorded three distinguished peaks during March, April-May and June (Fig. 6).

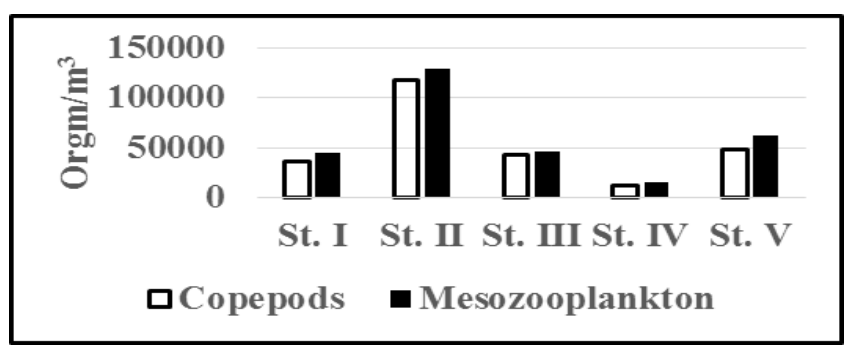

Fig. 5: The annual average count of total mesozooplankton and copepods at the sampling stations.

Copepods dominated the total mesozooplankton count by $86.4 \%$, while all other holoplankton groups formed $5 \%$ and meroplankton $8.6 \%$. However, the role of these components appeared different at the sampling stations, whereas copepods formed 91.0 and $91.4 \%$ of the total mesozooplankton at the high salinity stations (II, III), decreased to 82.2 and 80.4 at stations I and IV, and reached the minimum (77.6\%) at station V. Meanwhile, copepods abundance displayed similar pattern to that of the total mesozooplankton on the spatial scale (Fig. 5), as well as the temporal scale (Fig. 6). The nauplii larvae were responsible for $70.5 \%-78 \%$ of copepod population at the sampling stations, while copepodite stages formed $3.7 \%-11.9 \%$.

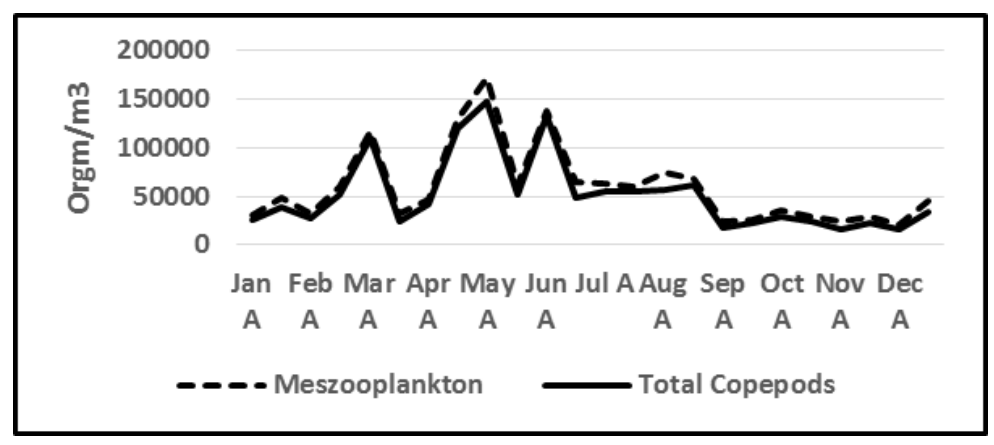

Fig. 6: Biweekly count of mesozooplankton and total copepods in the study area.

The adult copepods demonstrated pronouncedly small contribution, but the three major copepod groups had different contributions. The cyclopoids constituted $75.0 \%$ of the adults count, against $6.1 \%$ for calanoids and $18.9 \%$ for harpacticoids. As shwon in Figure 7, cyclopoids attained pronouncedly higher counts at stations I,II and V than at stations III and IV, but harpacticoids recorded the highest count at station II, high count at stations I and V, and dropped at stations IV. In the meantime, calanoids sustaiend mostly low count. The abundance cycle showed different patterns for the three groups, including three peaks for cyclopoids, four peaks for harpacticoids and one peak for calanoids, all in different timing (Fig. 8). 


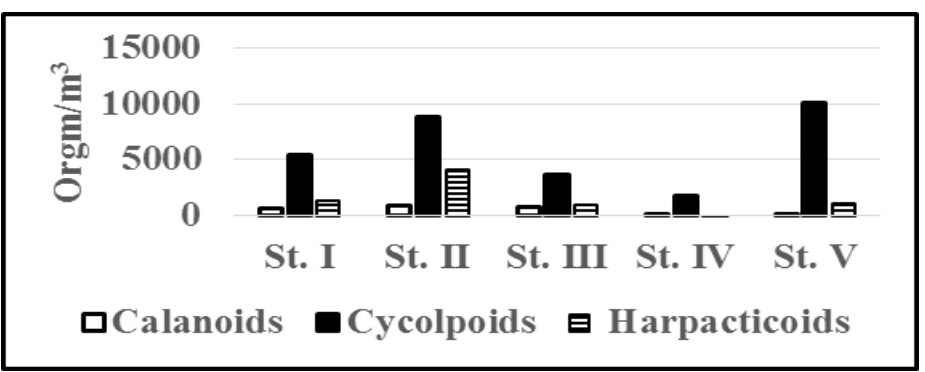

Fig. 7: The annual average count of major adult groups at the sampling sites.

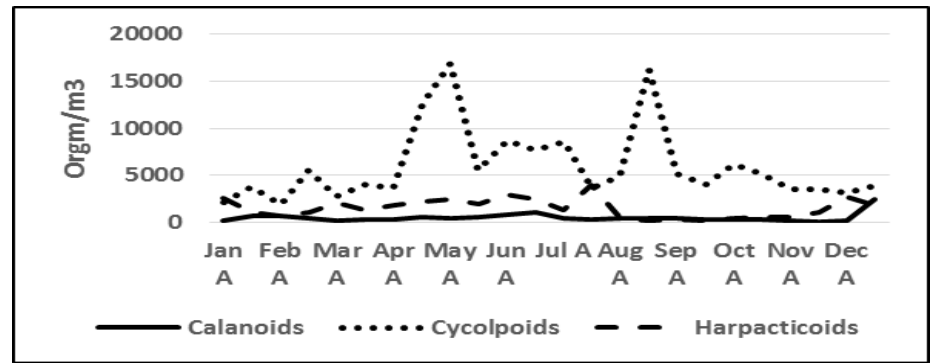

Fig. 8. Biweekly abundance of the adult copepod groups in the study area.

Oithona nana (Giesbrecht, 1893) was the most abundant adult cyclopoid (55.4 $-62.5 \%$ ) at the high salinity stations, dropped to $18.5 \%$ and $1.2 \%$ respectively at the low salinity stations. Similarly, other species showed relatively more active contribution at the high salinity than at the low salinity, like the cyclopoids Oithona plumifera (Baird, 1843), Ergasilus sieboldi (Nordmann, 1832), the harpacticoids Nitokra lacustris (Schmankevitch, 1875), Euterpina acutifrons (Dana, 1847), and the calanoid Paracalanus parvus (Claus, 1863). At the low salinity, the fresh water cyclopoids Halicyclops magniceps (Lilljeborg, 1853) formed 33.3 - 34.6\% of the adult copepods, followed by 31.7 - 32.9\% for Acanthocyclops americanus (Sars, 1863 ) and 6.5 - $19.5 \%$ for Cyclops vernalis (Fischer, 1853).

Other crustacean groups, including cladocerans, ostracods, and amphipods accounted totally for $2.6 \%$ of the total mesozooplankton. Cladocerans were abundant and persistent, particularly at the low salinity stations, mainly due to Moina micrura (Kurz, 1875). which attained a maximum of $21818 \mathrm{orgm} / \mathrm{m}^{3}$ (18\% of total mesozooplankton) in early May at station V.

The ostracods were represented mainly by Cyprea sp. and Candona sp., and persisted at stations II, IV and V. Cyprea sp. frequently attained high counts (2000 $2727 \mathrm{orgm} / \mathrm{m}^{3}$ ) over the year, particularly at station V. Amphipods were missed from the area most of the year, except in a few occasions, recording the highest count (1637 - $2424 \mathrm{orgm} / \mathrm{m}^{3}$ ) during March and early April at station II.

The planktonic crustacean groups displayed different frequency of occurrence relative to the total number of collected samples during the period of study. As shown in Table 3, cyclopoids appeared as the most persistent component, existing at all sampling stations over the whole year. Harpacticoids were observed in $83.3 \%-100$ $\%$ at most stations, decreased to $45.8 \%$ at station IV, while calanoids were persistent $(100 \%)$ at stations I and II, less persistent $(83.3 \%)$ at stations III, and became less frequent $(20.8 \%$ and $8.3 \%$ ) at stations IV and V respectively. The other crustacean groups showed less persistence, with variable percentage of frequency at the sampling stations (Table 3). Cladocerans were more persistent $(66.7 \%-87.5 \%)$ at the low salinity stations, and comparatively less persistent at the high salinity, meanwhile ostracodes displayed irregular persistence regardless to the salinity distribution in the study area. Furthermore, cnidarians, pteropods and larvaceans were restricted to the 
high salinity, but nematodes showed high percentage of frequency at all the sampling statins, with higher percentage at the low salinity stations (Table 3).

Since the crustaceans were the major component of the mesozooplankton, the TWINSPAN analysis based on a data set of 120 samples (Fig. 9) containing all crustaceans in the study area. This analysis displayed four significantly different groups (A-D) at level 2 of the sample hierarchy.

Group A: comprises 20 samples, mostly from station $\mathrm{V}$ and indicated by Onychocamptus mohammed (Blanchard \& Richard, 1891) and Canthocamptus glacilis (Lilljeborg, 1902) These samples are subdivided into two groups, A. americanus that indicated the negative one and Arctodiaptomus saltillinus (Brewer, 1898) indicating the positive and mostly at station V.

Group B: includes 32 samples, 22 of them belong to station IV and indicated by Cyclops vernalis, Bosmina longirostris (O.F.Müller, 1785), and Ceriodaphnia reticulata (Jurine, 1820), the indicator species of groups A and B are freshwater species.

Group C: comprised 43 samples, 15 of them from station III and 17 from station I. The indicator species was Centropages kroyeri (Giesbrecht, $1892(\mathrm{~F}, \mathrm{M})$, and $O$. plumifera.

Group D: comprised 25 samples, which mostly belong to station II, with $O$. plumifera, E. acutifrons, Acartia clause (Giesbrecht, 1889), N. lacustris, and Gammarus aequicauda (Martynov, 1931) as indicator species.

Table 3: The frequency of occurrence $(\%)$ and the mean abundance $\left(\times 10^{3} \mathrm{orgm} / \mathrm{m}^{3}\right)$ of different crustaceans at the sampling stations.

\begin{tabular}{lcccccc}
\hline$\underline{\text { Taxa }}$ & \multicolumn{1}{c}{ I } & II & III & IV & V & Total \\
\hline Calanoida & $100(0.665)$ & $100(0.857)$ & $83.3(0.79)$ & $20.8(0.044)$ & $8.3(0.042)$ & 62.5 \\
Cyclopoida & $100(5.47)$ & $100(8.777)$ & $100(3.644)$ & $100(1.732)$ & $100(10.088)$ & 100 \\
Harpacticoida & $91.7(1.274)$ & $100(4.114)$ & $95.8(0.878)$ & $45.8(0.103)$ & $83.3(1.026)$ & 83.3 \\
Cladocera & $25(0.063)$ & $50(0.42)$ & $16.7(0.17)$ & $66.7(0.79)$ & $87.5(3.26)$ & 49.17 \\
Ostracoda & $58.3(0.89)$ & $75(0.43)$ & $33.3(0.091)$ & $54.2(0.21)$ & $87.5(1.9)$ & $61.7(0.54)$ \\
Amphipoda & $33.3(0.034)$ & $29.2(0.26)$ & $16.7(0.017)$ & $4.2(0.0004)$ & $0.0(0.0)$ & 16.7 \\
Mysidacea & $0.0(0.0)$ & $4.2(0.0004)$ & $0.0(0.0)$ & $0.0(0.0)$ & $4.2(0.0004)$ & 1.67 \\
Cnidaria & $37.5(0.057)$ & $41.7(0.18)$ & $20.8(0.06)$ & $0.0(0.0)$ & $0.0(0.0)$ & $20(.068)$ \\
Nematoda & $75(0.74)$ & $41.7(0.26)$ & $45.8(0.37)$ & $79.2(1.37)$ & $87.5(3.39)$ & $65.8(1.23)$ \\
Pteropods & $29.2(0.24)$ & $29.2(0.053)$ & $4.2(0.008)$ & $0.0(0.0)$ & $0.0(0.0)$ & $12.5(0.06)$ \\
Chaetognatha & $16.7(0.02)$ & $25(0.43)$ & $8.3(0.008)$ & $0.0(0.0)$ & $0.0(0.0)$ & $10(0.014)$ \\
Larvacea & $33.3(0.08)$ & $41.7(0.086)$ & $41.7(138.9)$ & $4.2(0.008)$ & $4.2(0.26)$ & $25(0.068)$ \\
Polychaetes & $91.67 *(2.23)$ & $95.83 *(3.69)$ & $91.67 *(1.72)$ & $70.83 *(0.24)$ & $87.5 *(4.7)$ & $87.5 *(48.9)$ \\
Bivalve & $83.3 *(17.96)$ & $70.8 *(3.32)$ & $66.7 *(4.53)$ & $20.8 *(1.36)$ & $4.2 *(2.42)$ & $40.2 *(35.3)$ \\
Cirripedes lar. & $83.3 *(24.8)$ & $75.0 *(57.64)$ & $70.8 *(7.55)$ & $37.5(0.88)$ & $25.0(0.0004)$ & $58.3 *(11.5)$ \\
Other & $3.0(1.8)$ & $2.0(0.9)$ & $2.0(5.5)$ & $3.0(30.8)$ & $2.5(9.6)$ & $2.5(4 . .27)$ \\
\hline
\end{tabular}

The multivariate analysis

The DCA recorded a maximum of 2.56 , suggesting either linear or unimodal relationship between crustaceans and environmental parameters. The results of CCA analysis indicated that the environmental parameters had a significant influence on crustaceans distribution $(F$-ratio $=4.954, P<0.001)$, explaining $48.5 \%$ of the total variance. The Monte Carlo test revealed that seven environmental parameters had significant influences on the distribution of crustacean species, with more pronounced effect of salinity, chlorophyll $a$, and temperature (Table 4). 
Table 4: Results of forward selection and Monte Carlo permutation Tests from CCA.

\begin{tabular}{lccc}
\hline Physiochemical parameters & Lambda-A & P-value & F-ratio \\
\hline Salinity & 0.28 & 0.001 & 28.28 \\
Chlorophyll $a$ & 0.07 & 0.001 & 7.42 \\
Temperature $\left({ }^{\circ} \mathrm{C}\right)$ & 0.03 & 0.001 & 2.86 \\
$\mathrm{NO}_{3}$ & 0.01 & 0.005 & 2.06 \\
$\mathrm{PO}_{4}$ & 0.02 & 0.004 & 1.97 \\
$\mathrm{SiO}_{3}$ & 0.02 & 0.002 & 2.14 \\
$\mathrm{Turbidity}_{\mathrm{NH}}$ & 0.02 & 0.012 & 1.82 \\
$\mathrm{pH}$ & 0.01 & 0.066 & 1.49 \\
$\mathrm{DO}$ & 0.01 & 0.287 & 1.13 \\
$\mathrm{NO}_{2}$ & 0.01 & 0.553 & 0.94 \\
\hline
\end{tabular}

As shown in Figure 10, amphipods and about $56 \%$ of copepods were found in the right half of the ordination diagram where the gradients of salinity, $\mathrm{DO}, \mathrm{pH}$, the lowest nutrients and chlorophyll $a$ were demonstrated, especially at stations I, II, and III. On the other hand, ostracods and about $78 \%$ of cladocerans were associated mainly with the low salinity, the gradients of nutrients and phytoplankton biomass at stations IV and V. Clytemnestra scutellata (Dana, 1847), Cyclops minutus (Claus, 1863) C. vernalis, Moina micrura, Candona sp., and Cyprea sp. were associated with the gradients of silicate and phytoplankton biomass, especially at station V.

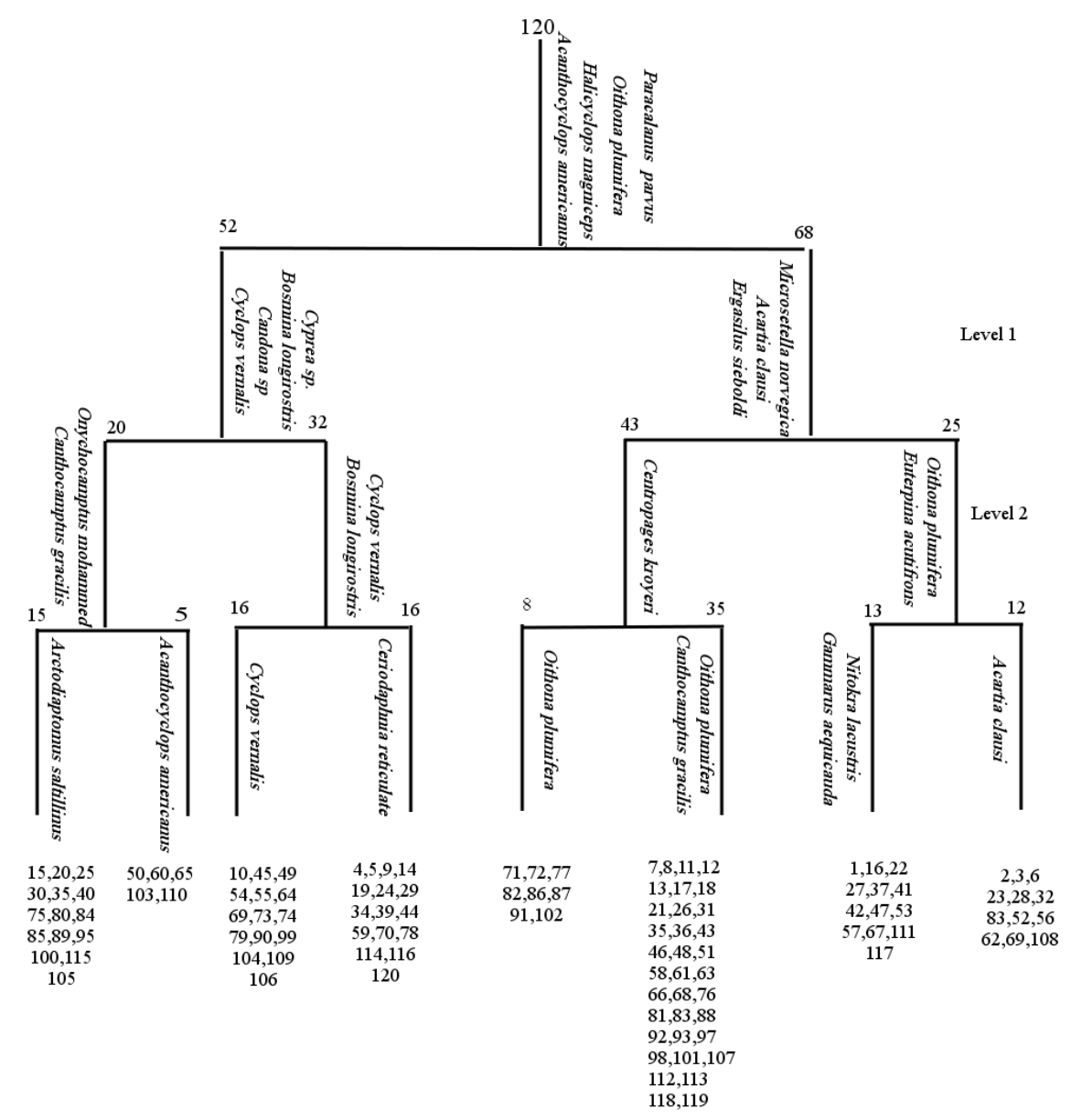

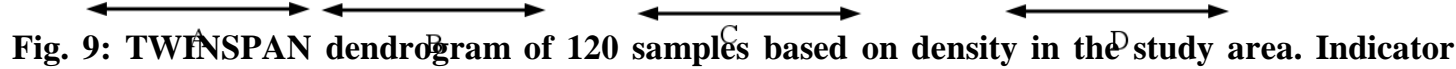
species are shown at each level of classification. Four groups (A-D) are shown at level 2. 
The vector of turbidity found between the sample units of stations IV and V; the cyclopoid $A$. americanus and $H$. magniceps, and the cladoceran Euryalona occidentalis (Sars, 1901) were associated also with turbidity. The cladocerans $B$. longirostris and Ceriodaphnia cornuta (Sars, G.O., 1885) accompanied the highest nitrogen concentrations and the lowest salinity at station IV. The species which close to the point of the origin (0.0) of the diagram ( $N$. lacustris and copepod nauplii and copepodides) indicated their wide distribution in the study area. Most of the other species like A. clausi, Acartia grani (Sars, G.O., 1904), E. acutifrons, Microsetella norvegica (Boek, 1865), O. nana, O. plumifera, P. parvus, and G. aequicauda were associated with the highest salinity, low nutrients and phytoplankton biomass.

Beside the crustaceans, some other mesozooplankton groups were found in the coastal water of the Nile Delta, namely cnidarians, nematodes, pteropods, larvaceans and chaetognaths, with greatly variable counts (Table 3). Nematodes were abundant and persistent at most stations, with counts up to $17,272 \mathrm{orgm} / \mathrm{m}^{3}$, particularly at station V. However, the nematodes population was pronouncedly poorer at the high salinity (annual average: $261-740 \mathrm{orgm} / \mathrm{m}^{3}$ ) than at the low salinity (annual average: $1,383-3,393$ orgm $/ \mathrm{m}^{3}$ ). Anonchus sp. and Dorylaimus sp. were the most abundant nematodes over the whole area of study, with clearly higher counts at the low salinity. Anonchus sp. was persistent at the high salinity station I as well as at the low salinity stations, while Dorylaimus sp. and Ethmoliamus sp. were abundant at the low salinity. The highest peak of nematodes occurred in May at station V, forming $14.3 \%$ of the total metazooplankton, due to the abundance of Anonchus sp., Ethmoliamus sp., and Dorylaimus sp. respectively.
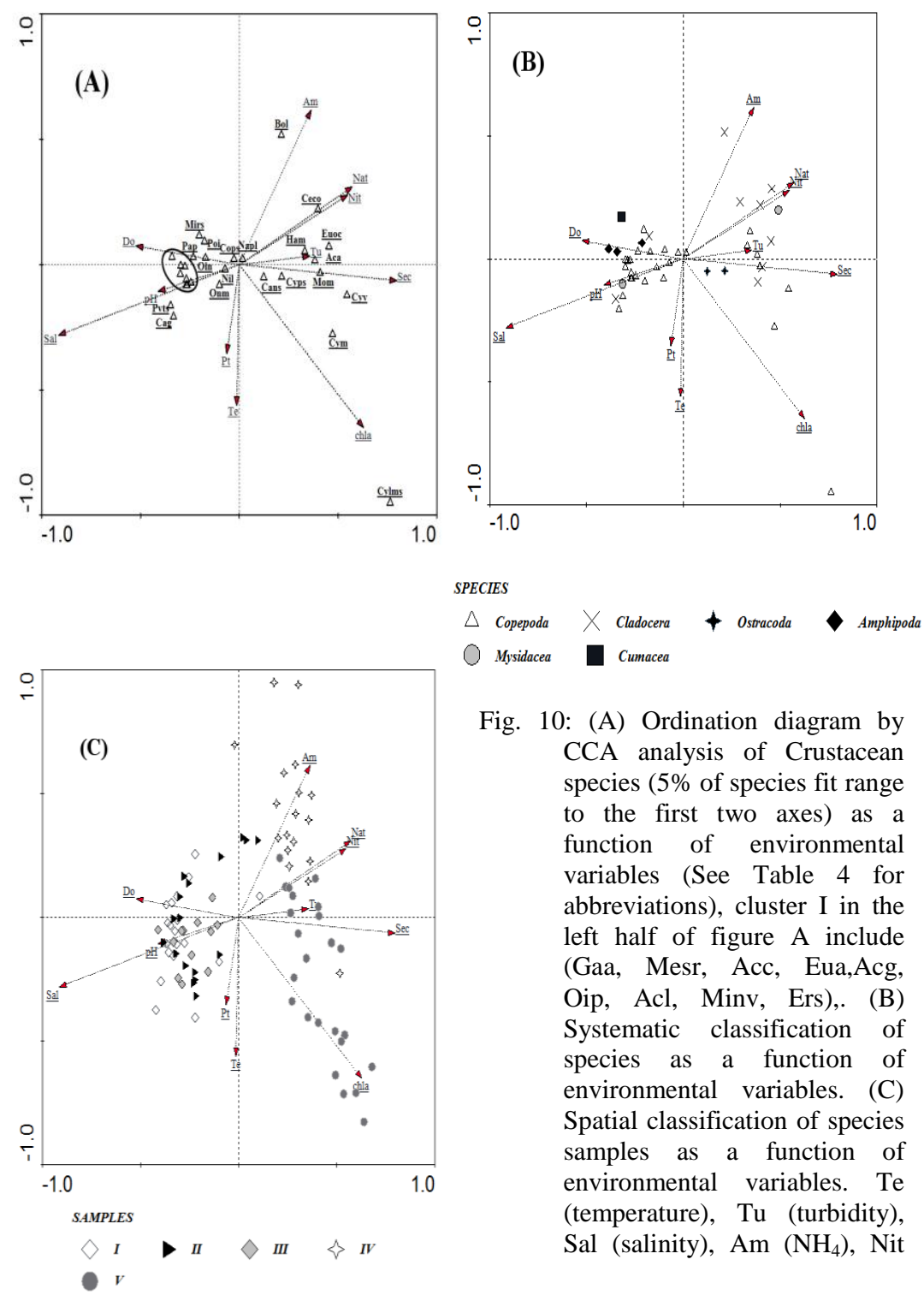

Fig. 10: (A) Ordination diagram by CCA analysis of Crustacean species $(5 \%$ of species fit range to the first two axes) as a function of environmental variables (See Table 4 for abbreviations), cluster I in the left half of figure A include (Gaa, Mesr, Acc, Eua,Acg, Oip, Acl, Minv, Ers),. (B) Systematic classification of species as a function of environmental variables. (C) Spatial classification of species samples as a function of environmental variables. Te (temperature), $\mathrm{Tu}$ (turbidity), Sal (salinity), Am $\left(\mathrm{NH}_{4}\right)$, Nit 
Larvaceans were represented by Oikopleura dioica (Lohmann, 1933) and Appendicularia sicula (Fol, 1874), with clear abundance of the former species (up to $606 \operatorname{orgm} / \mathrm{m}^{3}$ ), particularly at the high salinity stations (I-III) during spring and summer. Cnidarians occurred intermittently at high salinity stations, reaching a maximum of $1,414 \mathrm{orgm} / \mathrm{m}^{3}$ in early June at station II. The planktonic pteropod molluscs comprised only Limacina inflata (d'Orbigny, 1834) which appeard only at the high salinity station I, attaining relatively high count (up to $1818 \mathrm{orgm} / \mathrm{m}^{3}$ ) from August to early October. One species only of Chaetognatha, Parasagitta friderici (Ritter-Zahony, 1911) occurred intermittently in low counts at the high salinity stations, increased to $404 \mathrm{orgm} / \mathrm{m}^{3}$ in early July at station II.

The meroplankton displayed relatively low contribution $(8.6 \%)$ to the total mesozooplankton in the study area, with the highest percentage $(14.8 \%)$ at station I, and the lowest role (4.3\%) at station IV. Polychaetes larvae comprised $48.9 \%$ of the total meroplankton, followed by lamellibranch veligers (35.3\%) and Cirripedes larvae $(11.5 \%)$. Figure 11 illustrates that polychaetes larvae had smaller role at stations I, II and IV, as compared to stations III and V, while lamellibranch veligers displayed less active role at stations IV and III than at stations I and II, and completely disappeared at station $\mathrm{V}$. In the meantime, cirripedes larvae showed the highest contribution at stations I and IV, and became less abundant at stations II, III and V. It is to be noticed that active role was observed for insects (19.2\%) and fasciola (10.0\%) at station IV.

The meroplankton demonstrated different biweekly distribution along the study area, but the larvae of polychaetes and lamellibranchs followed the distrbutional pattern of the total meroplankton, while cirripedes larvae displayed slightly different pattern (Fig. 12). The polychaetes larvae were the most frequent meroplanktonic group, occurring in $70.8-95.8 \%$ of the collected samples, while the larvae of both lamellibranchs veligers and cirripedes were pronouncedly less frequent, particularly at the low salinity stations (Table 3).

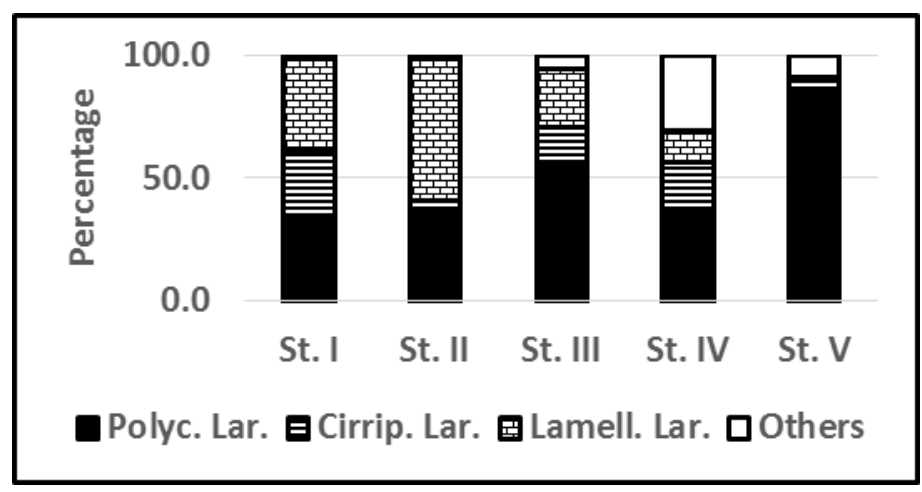

Fig. 11: Relative abundance (\%) of the different meroplankton groups to the total meroplankton at the sampling stations.

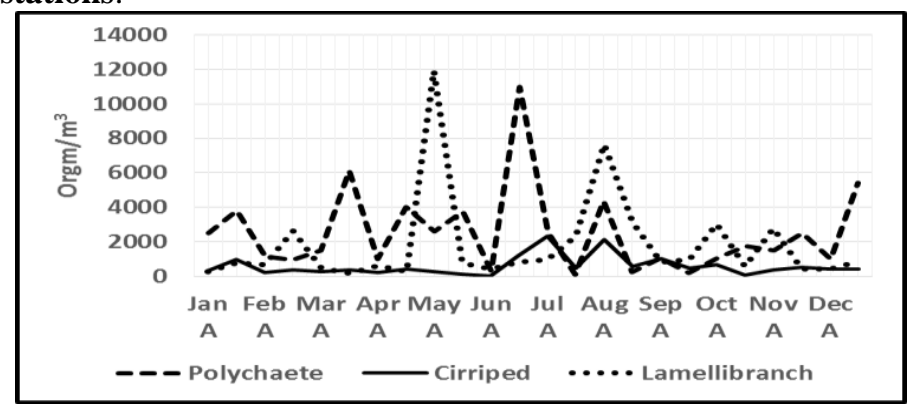

Fig. 12: Biweekly abundance of the total and major Meroplankton groups in the study area. 


\section{DISCUSSION}

The present study recorded 59 mesozooplankton species in the coastal water of the Nile Delta. This number was pronouncedly higher than earlier records along the Damietta coast (El-Tohamy et al. 2017; El-Tohamy et al. 2019), but lower than those observed off the Nile Delta coast (Abdel-Aziz and Abu-El Ezz, 2003). The higher number of species during the present study may be attributed to the environmental differences among the sampling stations and the occurrence of several freshwater forms. Salinity played crucial role in the distribution of mesozooplankton species throughout the study area, as indicated from the positive significant correlation between the two parameters $(\mathrm{r}=0.4363, \mathrm{n}: 120, \mathrm{p}<0.05)$. This was also clear from the preference of some species to the high salinity and others to low salinity. The high salinity species comprised A. clausi, A. grani, A. latisetosa, C. kroyeri, Leptocaris brevicornis (Douwe, 1904), Mesochra rapiens (Schmeil, 1894), M. norvegica, Microsetella rosea (Dana 1847), Evadne sp., Podon intermedius (Lilljeborg, 1853), Elasmopus sp., Gammarus sp., Hyperia sp., Appendicularia sp., and Sagitta sp. The low salinity species were represented by the cladocerans $C$. cornuta, $C$. reticulata, Daphnia sp., Diaphanosoma sp., Euryalona sp., and the calanoid A. saltillinus. This was in consistent with earlier observations which stated that salinity has been considered as the main environmental factor, pronouncedly affecting the structural and functional characteristics of aquatic biota in estuaries (Dorgham and Hussein, 1997; Marques et al. 2007, Telesh and Khlebovich (2010). Other environmental factors like turbidity, $\mathrm{pH}, \mathrm{DO}$, ammonia, nitrite, nitrate, and silicate appeared to be effective on the community structure, whereas significant correlations were observed between the environmental parameters and both the number of species and evenness of the mesozooplankton (Table 5 ).

Table 5: Pearson's correlation coefficient between diversity indices of mesozooplankton community and environmental parameters.

\begin{tabular}{lcccc}
\hline & Sp. no. & $\mathrm{H}^{\prime}$ & $\mathrm{J}^{\prime}$ & $\mathrm{D}$ \\
\hline Temp. & $\mathrm{ns}$ & $-^{\mathrm{x}}$ & $\mathrm{ns}$ & $\mathrm{ns}$ \\
Turbidity & $-\mathrm{xxx}^{\mathrm{xx}}$ & $\mathrm{ns}$ & ${ }_{\mathrm{xx}}$ & $\mathrm{ns}$ \\
Salinity & $\mathrm{xxx}$ & $\mathrm{ns}$ & $-{ }^{\mathrm{xxx}}$ & $\mathrm{xx}$ \\
pH & $\mathrm{xx}$ & $\mathrm{ns}$ & $-{ }^{\mathrm{xx}}$ & $\mathrm{ns}$ \\
DO & $\mathrm{xxx}$ & $\mathrm{ns}$ & $-{ }^{\mathrm{xx}}$ & $\mathrm{ns}$ \\
Ammonia & $-{ }_{\mathrm{xx}}$ & $\mathrm{ns}$ & $\mathrm{ns}$ & $\mathrm{ns}$ \\
Nitrite & $-{ }_{\mathrm{xxx}}$ & $\mathrm{ns}$ & $\mathrm{xxx}$ & $\mathrm{ns}$ \\
Nitrate & $-\mathrm{xxx}^{\mathrm{xx}}$ & $\mathrm{ns}$ & $\mathrm{xxx}$ & $-{ }_{\mathrm{x}}$ \\
Silicate & $-{ }^{\mathrm{xx}}$ & $\mathrm{ns}$ & ${ }_{\mathrm{xxx}}$ & $\mathrm{ns}$ \\
Chl. & $\mathrm{ns}$ & $\mathrm{xx}$ & $\mathrm{xxx}$ & $-{ }_{\mathrm{xx}}$ \\
\hline
\end{tabular}

Correlation is significant at $0.001(x \times x)$, at the $0.01(x x)$, at the $0.05(x)$.

The variation of species diversity could be used as an index for the degree of environmental stress (Omori and Ikeda, 1984), as the pollution causes disappearance of sensitive species and high abundance of the most tolerant species (Gray et al. 1979), and moderate eutrophy or oligotrophy renders a higher diversity (Pejler, 1983). These statements support our findings in the study area, whereas a few species were responsible for the total mesozooplankton count, like $O$. nana at the high salinity and H. magniceps, A. americanus and Cyclops vernialis at the low salinity. This pattern was resulted in low diversity (1.44 -1.87), low dominance index (0.19-0.48) and high evenness (0.64 - 0.86). These situations could be attributed to the eutrophic conditions, which dominated in the area of study most of the year. The temporal 
variation of evenness may be due to the predominance of some species in different times, the effect of food availability, and biotic relationships among the species (Takahashi et al. 2014). Although the area of the present study could be considered as stressed area, the dominance index was low, and showed significant positive correlation with salinity and significant negative correlation with chlorophyll. Such conditions may indicate that the high phytoplankton bloom was not favourable for the dominance of the majority of mesozooplankton species. The low Shannon index reflects the stress effect on zooplankton community (Mokhayer et al. 2017), which is highly susceptible to suspended sediments (Thorp and Mantovani, 2005).

The mesozooplankton abundance during the present study $\left(59.7 \times 10^{3} \mathrm{orgm} / \mathrm{m}^{3}\right)$ was higher than those in earlier records (El-Tohamy et al., 2017; 2019). This could be explained by the high phytoplankton biomass, which is used as food for several copepods species in addition to the high contribution of some fresh water species. Similar observations were recorded in other areas (Bonecker et al. 2007; Serafim-Ju' nior et al. 2010). However, the mesozooplankton showed different correlations with the environmental parameters at the sampling stations (Table 6). Such pattern could be explained by the difference in the abundance of mesozooplankton and in community structure, as every species, particular the dominant ones, has its own response to the surrounding conditions.

Table 6: Pearson's correlation coefficient between mesozooplankton groups and the environmental parameters at the sampling stations.

\begin{tabular}{lccccc}
\hline & St I & St II & St III & St IV & St V \\
\hline Salinity & ns & $\times \times$ & $\times \times$ & $n s$ & $n s$ \\
Turbidity & ns & ns & ns & ns & $-\times$ \\
pH & $-\times \times$ & $\times \times$ & $n s$ & $n s$ & $n s$ \\
DO & $-\times \times \times$ & $n s$ & $n s$ & $-\times$ & $n s$ \\
$\mathrm{NH}_{4}$ & $-\times \times$ & $\times \times$ & $-\times$ & $n s$ & $n s$ \\
Chl. & $\times$ & ns & $-\times$ & ns & $-\times \times$ \\
\hline
\end{tabular}

Correlation is significant at the $0.01(x \times x)$, at $0.05(x \times)$, at $0.1(x)$.

The water temperature was accounted as essential factor in the dynamics of zooplankton, as it may regulate most ecological mechanisms in temperate areas (Sellami et al. 2010). Our findings revealed that water temperature had significant negative correlation with the diversity index, but it was not correlated with mesozooplankton count. However, the mesozooplankton count and species number were low during autumn and early winter at wide temperature range $\left(12.5-25^{\circ} \mathrm{C}\right)$ and the highest during spring at a temperature range of $23-26{ }^{\circ} \mathrm{C}$. Such pattern indicated that the high water mixing in the study area may be fundamental in temporal variations of mesozooplankton abundance and species number, rather than the temperature.

Copepods were pronouncedly less diverse and more abundant in the study area than those recorded in offshore Egyptian Mediterranean waters. Copepods are frequently dominant in most of the estuaries and coastal areas (Day et al. 1989), but with lower species richness (Goswami and Selvakumar, 1977). Although phytoplankton serve as essential food for many copepods (Fulton, 1984) no corelation was reocrded btween the two parameters during the present study.

The numerical abundance ranking (0.5: 5.9: 1.1) of the major copepod groups (calanoids, cyclopoids, and harpacticoids respectively) indicated the dominance of cyclopoids, and was close to that (1:3.5:1.1) recorded earlier in Damietta coast (El- 
Tohamy, 2005). The dominance of cyclopoids in aquatic area was considered as indication of eutrophication (Waller et al. 2002; Santos-Wisniewski and Rocha, 2007). In addition, the ratios between some zooplankton groups (rotifers, copepods and cladocerans) are used to indicate the trophic condition of the water body, as these ratios are also affected by eutrophication (Sendacz et al. 2006; Bini et al. 2007), while certain cyclopoid species were used as indicators of water quality in tropical reservoirs (Silva, 2011).

The cladocerans distribution in our area was affected by salinity, as indicated from their significant negative correlation and the occurrence of three marine species at the high salinity and seven freshwater forms at the low salinity. In addition, this group showed significant negative correlation with DO, and significant positive correlation with chl. $a$. The cladocerans were dominated by the freshwater $M$. micrura, particularly at station $\mathrm{V}$ and B. longirostris at station IV. This is a common species in eutrophic waters and can be indicator of eutrophication (Wang et al. 2010).

It is well known that the abundance of meroplankton is usually associated with the numerical density and reproductive efficiency of the benthic animals. During the present study, meroplankton displayed significant positive correlation with both salinity and $\mathrm{pH}$ and significant negative correlation with turbidity. Polychaetes larvae were the abundant meroplankton group and widely distributed over the whole area regardless of the environmental differences among the sampling stations. This may be attributed to the ability of polychaetes to regulate the pollutants and resist the organic contaminants and pesticides (Dean, 2008) and their tolerance to polluted conditions (Croquer et al. 2016).

In contrast, the lamellibranchs veligers and cirripedes larvae exhibited significant positive correlation with salinity and $\mathrm{pH}$, and significant negative correlation with turbidity (Table 7). This means that both groups are susceptible to the low salinity, and they can tolerate high turbidity. Jeffries (1964) stated that the filter feeding lamellibranchs were adversely affected by the high turbid water, and the abundant phytoplankton may have been responsible for delay reproduction of adult cirripedes.

Table 7: Non parametric Spearman's correlation between total meroplankton, main meroplanktonic larvae and environmental parameters.

\begin{tabular}{cccc}
\hline & $\begin{array}{c}\text { Lamellibranch } \\
\text { veliger }\end{array}$ & $\begin{array}{c}\text { Polychaete } \\
\text { larvae }\end{array}$ & $\begin{array}{c}\text { Cirripeds } \\
\text { larvae }\end{array}$ \\
\hline Temperature & $\mathrm{ns}$ & $\mathrm{ns}$ & $\mathrm{ns}$ \\
Turbidity & $-\times$ & $\mathrm{ns}$ & $-\times$ \\
Salinity & $\times \times$ & $\mathrm{ns}$ & $\times \times \times$ \\
pH & $\times$ & $\mathrm{ns}$ & $\times \times$ \\
$\mathrm{DO}$ & $\mathrm{ns}$ & $\mathrm{ns}$ & $\mathrm{ns}$ \\
$\mathrm{NO}_{3}$ & $\mathrm{~ns}$ & $\mathrm{~ns}$ & $-\times$ \\
$\mathrm{NO}_{2}$ & $\mathrm{~ns}$ & $\mathrm{~ns}$ & $-\times$ \\
$\mathrm{NH}_{4}$ & $\mathrm{~ns}$ & $\mathrm{~ns}$ & $\mathrm{~ns}$ \\
$\mathrm{PO}_{4}$ & $\mathrm{~ns}$ & $\mathrm{~ns}$ & $\mathrm{~ns}$ \\
$\mathrm{SiO}_{3}$ & $-\times$ & $\mathrm{ns}$ & $\mathrm{ns}$ \\
$\mathrm{Chlorophyll} a$ & $\mathrm{~ns}$ & $\mathrm{~ns}$ & $\mathrm{~ns}$ \\
\hline
\end{tabular}

Correlation is significant at $0.001(x \times x)$, at $0.01(x \times)$, at $0.05(x)$. 


\section{CONCLUSION}

In conclusions, the present study revealed that the mesozooplankton community of the Nile Delta coast was characterised by high number of species and great numerical abundance as compared to earlier studies in the same area. Both the species number and numerical abundance were clearly different among the sampling stations and displayed pronounced biweekly variations. The changeable environmental parameters appeared to play essential role in the dynamics of the mesozooplankton community, whereas the distribution and abundance of the different groups as well as of the dominant species were significantly correlated the environmental parameters.

\section{REFERENCES}

Abdel-Aziz, N. E. (2006). Vertical migration of zooplankton groups in an eutrophic bay, Dekhaila Harbor, Alexandria, Egypt. The Egyptian Journal of Aquatic Research 32 (1): 135-157.

Abdel-Aziz, N. E. and Aboul-Ezz, S. M. (2003). Zooplankton community of the Egyptian Mediterranean coast. Egyptian Journal of Aquatic Biology \& Fisheries, 7(4): 91-108.

Abdel-Aziz, N. E., Dorgham, M. M., Ghobashi, A. E. and El-Tohamy, W. S. (2007). Qualitative and quantitative study of copepods in Damietta Harbor, Egypt. The Egyptian Journal of Aquatic Research 33(1): 144-162.

Abdel-Aziz, N. M.; Gharib, S.M. and Dorgham, M. M. (2006). The interaction between phytoplankton and zooplankton in a Lake-Sea connection, Alexandria, Egypt. International Journal of Oceans and Oceanography 1(1): 151-165.

Abo-Taleb, H. A. (2014). Zooplankton in the Mediterranean Sea and the River Nile, Egypt dynamics of zooplankton community in the connection between the Mediterranean Sea and the River Nile at Rosetta Branch. M.Sc. Thesis, Azhar University.

Abo-Taleb, H. A; Abdel-Aziz, N. E.; Aboul-Ezz, S. M., El-Raey, M. and Abou-Zaid, M.M. (2016). Study of Chromista and Protozoa in a Hotspot area at the Mediterranean Coast with Special Reference to the Potentiality to Use It as Bioindicators. International Journal of Marine Science, 6(53): 1-17.

Abou-Zaid, M. M.; El-Raey, M.; Aboul-Ezz, S. M., Abdel-Aziz, N. E. and AboTaleb, H. A. (2014). Diversity of Copepoda in a Stressed Eutrophic Bay (ElMex Bay), Alexandria, The Egyptian Journal of Aquatic Research 40: 143-162.

Aboul-Ezz, S. M.; Heneash, A. M. M.; Gharib, S. M. (2014a). Variability of spatial and distribution of zooplankton communities at Matrouh beaches, south-eastern Mediterranean Sea. Egypt. Egyptian Journal of Aquatic Research, 40: 283-290.

Aboul-Ezz, S. M.; Abdel-Aziz, N. E.; Abou-Zaid, M. M.; El-Rae, M. nad Abo-Taleb, H. A. (2014b). Environmental assessment of El-Mex Bay, Southeastern Mediterranean by using Rotifera as a plankton bioindicator. The Egyptian Journal of Aquatic Research, 40(1): 43-57.

Bini, L. M.; Vieira, L. C. G.; Machado, J. and Velho, L. F. M. (2007). Concordance of Species Composition Patterns among Microcrustaceans, Rotifers and Testate Amoebae in a Shallow Pond. Hydrobiologia 92(1): 9-22.

Bonecker, C. C.; Nagae, M.Y.; Bletller, M. C. M.; Velho, L. F. M. and Lansac-Toha, F. A. (2007). Zooplankton biomass in tropical reservoirs in southern Brazil. Hydrobiologia 579: 115-123. 
Croquer, A.; Bone, D.; Bastidas, C.; Ramos, R. and Garcı'a, E. (2016). Monitoring coastal pollution associated with the largest oil refinery complex of Venezuela. Peer J 4:e2171; DOI 10.7717/peerj.2171.

Day, J. W. Jr.; Hall, C. A. S.; Kemp, W. M. and Yanez-Arancibia, A. (1989). Estuarine ecology. John Wiley, New York, 558 pp.

Dean, H. K. (2008). The use of polychaetes (Annelida) as indicator species of marine pollution: a review. Int. J. Trop. Biol., 56 (4): 11-38.

Dorgham, M. M.; Abdel-Aziz, N. E.; Ghobashy, A. E. and El-Tohamy, W. S. (2009). Preliminary study on protozoan community in Damietta Harbor, Egypt. Global Veterinaria (IDOSI), 3 (6): 495 - 502.

Dorgham, M. M.; El-Tohamy, W. S.; Abdel-Aziz, N. E.; El-Ghobashi, A. and Qin, J. G. (2013). Protozoa in a stressed area of the Egyptian Mediterranean coast of Damietta, Egypt. Oceanologia 55 (3): 733-750.

Dorgham, M. M.; El-Tohamy, W. S.; Qin, J. G.; Abdel-Aziz, N. E. and El-Ghobashi, A. (2019). Water quality assessment of the Nile Delta Coast, south eastern Mediterranean, Egypt. Egyptian Journal of Aquatic Biology \& Fisheries, 23(3): $151-169$.

Dorgham, M. M. and Hussein, M. M. (1997). Zooplankton dynamics in a neritic area of the Arabian Gulf (Doha Harbour). Arab Gulf Journal for Scientific Research 15(2): 415- 435.

El-Tohamy, W. S. (2005). Zooplankton community in Damietta Harbor,". M.Sc. Thesis, Mansoura University, Egypt.

El-Tohamy, W. S. (2012). Food relations between larvae of economic fishes and zooplankton in Some Egyptian coastal areas of the mediterranean sea. Ph.D. Thesis, Damietta University,Egypt, 228 pp.

El-Tohamy, W. S. (2015). Hydrography and Crustacean Zooplankton as Determinants of Rotifer Distribution and Density in Damietta Coast, Egypt. World Journal of Zoology 10 (4): 323-334.

El-Tohamy, W. S.; Dorgham, M. M.; Abdel-Aziz, N. E.; El-Ghobashi, A. E.; Bull, M. and Qin, J. G. (2012). Rotifers in ecologically stressed habitat along Damietta sea coast, Egypt. The $22^{\text {nd }}$ International Conference on "Environmental Protection is A Must", May 2012, Alexandria, Egypt.

El-Tohamy, W. S.; Alzeny, A. and Azab, Y. A. M. (2017). Zooplankton of a stressed area in the Damietta coast of the Mediterranean Sea. Acta Adriatica, 58(2): 245 -260 .

El-Tohamy, W. S.; Hopcroft, R. R. and Abdel-Aziz, N. E. (2018). Environmental Determinants of Zooplankton Community in the Damietta Estuary of the Nile River, Egypt. Pakistan Journal of Zoology., 50(5): 1601-1998.

El-Tohamy, W. S.; Azab, Y. A. M. and Abdel-Aziz, N. E. M. (2019). Evaluation of the Water Quality of Damietta Harbor: Using the Zooplankton Diversity and the Traditional Water Quality Parameters. International Journal of Oceans and Oceanography, 13(1): 229-246.

Falcão, J.; Marques, S. C.; Pardal, M. A.; Marques, J. C.; Primo, A. L. and Azeiteiro, U. M. (2012). Mesozooplankton structural responses in a shallow temperate estuary following restoration measures. Estuarine, Coastal and Shelf Science, 112: 23-30.

Fulton, R. S. (1984). Predation, production and the organization of an estuarine copepod community. Journal of Plankton Research, 6: 399-415.

Goswami, S. C. and Selvakumar, R. A. (1977). Plankton studies in the estuarine system of Goa. Proc. Symp. Warm Water Zooplankton, Goa, 226-241. 
Gray, J. S.; Waldichuk, M.; Newton, A. J.; Berry, R. J.; Holden, A. V. and Pearson, T. H. (1979). Pollution-induced changes in populations (and discussion). Philosophical Transactions of the Royal Society of London. B. Biological Sciences, $545 \mathrm{pp}$.

Gyllström, M.; Hansson, L. A.; Jeppesen, E. and Garcia-Criado, F. (2005). The role of climate in shaping zooplankton communities of shallow lakes. Limnology and Oceanography 50(6). DOI: $10.4319 / 10.2005 .50 .6 .2008$

Havens, K. E. and Hanazato, T. (1993). Zooplankton community responses to chemical stressors: a comparison of results from acidification and pesticide contamination research. Environ Pollution, 82: 277-288.

Heneash, A. M. M. (2015). Zooplankton composition and distribution in a stressed environment (El Dekhaila Harbour), South-Eastern Mediterranean Sea, Egypt. International Journal of Advanced Research in Biological Sciences, 2(11): 39-51.

Hossain, R. A.; Pramanik, M. H. and Hasan, M. (2017). Diversity indices of plankton communities in the River Meghna of Bangladesh. International Journal of Fisheries and Aquatic Culture, 5(3): 330-334.

Jakhar, P. (2013). Role of phytoplankton and zooplankton as health indicators of aquatic ecosystem: A review. International Journal of Innovation Research Study, 2(12): 489-500.

Jeffries, H. P. (1964). Comparative studies on estuarine zooplankton. Limnology and Oceanography, 9(3): 348-358.

Leonardo, K. M.; Mauro, M. J. and Rubens, M. L. (2009). Estuarine and oceanic influences on copepod abundance and production of a subtropical coastal area. Journal of Plankton Research, 31(8): 815-826.

Marques, S. C.; Pardal, M. A.; Pereira, M. J.; Gonçalves, F.; Marques, J. C. and Azeiteiro, U. M. (2007). Zooplankton distribution and dynamics in a temperate shallow estuary. Hydrobiologia, 587: 213-223.

Mokhayer, Z.; Mousavi, N. R.; Rabbaniha, M.; Fatemi, M. R. and Jamili, Sh. (2017). Community composition and diversity of zooplankton in the northwest Persian Gulf. Iranian Journal of Fisheries Sciences, 16(2): 722-732.

Neto, A. J. G.; Cristina da Silva, L.; Saggio, A. A. and Rocha, O. (2014). Zooplankton communities as eutrophication bioindicators in tropical reservoirs. Biota Neotropica, 14(4): e20140018.

Oliver, J. Hao. (1996). Bioindicators for water quality evaluation- A review. Journal of Chinese Institute of environmental Engineering, 6(1): 1-19.

Omori, M. and Ikeda, T. (1984). Methods in marine zooplankton ecology. John Wiley, New York, 332 pp.

Pejler, B. (1983). Zooplanktic indicators of trophy and their food. Hydrobiologia 101: 111-114.

Santos-Wisniewski, M. J. and Rocha, O. (2007). Spatial distribution and secondary production of Copepoda in a tropical reservoir: Barra Bonita, SP, Brazil. Brazilian Journal of Biology, 67(2): 223-233.

Sellami, I.; Guermazi, W.; Hamza, A.; Aleya, L.; Ayadi, H. (2010). Seasonal dynamics of zooplankton community in four Mediterranean reservoirs in humid area (BeniMtir: north of Tunisia) and semi arid area (Lakhmes, Nabhana and Sidi Saâd:center of Tunisia). Journal of Thermal Biology, 35: 392-400.

Sendacz, S.; Caleffi, S.; Santos-Soares, J. (2006). Zooplankton biomass of reservoirs in different trophic conditions in the state of $\mathrm{Sa}^{\sim}$ o Paulo, Brazil. Brazilian Journal of Biology, 66: 337-350. 
Serafim-ju, N. M.; Perbiche-Neves, G.; De Brito, L.; Ghidini, A. R. and Casanova, S. M. (2010). Variac, a o espac,otemporal de Rotifera em um reservato' rio eutrofizado no sul do Brasil. Iheringia Serrie Zoologia, 100(3): 233-241.

Silva, W. M. (2011). Potential use of Cyclopoida (Crustacea, Copepoda) as trophic state indicators in tropical reservoirs. Oecologia, 15(3): 511- 521.

Sousa, V. S. de; Louvandini, H. ; Scropfner, E. dos S. ; McManus, C. M. ; Abdalla, A. L. ; Garcia, J. A. S. (2008). Performance, carcass traits and body components in hair sheep fed with sunflower silage and corn silage. Cienc. Anim. Bras., 9 (2): 284-291.

Takahashi, É. M.; Lansac-Tôha, F. A.; Dias, J. D. and Bonecker, C. C. (2014). Daily variation of zooplankton abundance and evenness in the Rosana reservoir, Brazil: biotic and abiotic inferences. Iheringia, Série Zoologia, Porto Alegre, 104(1): 21-31.

Telesh, I. V. and Khlebovich, V. V. (2010). Principal processes within the estuarine salinity gradient: A review. Marine Pollution Bulletin, 61: 149-155.

Thorp, J. H. and Mantoyani, S. (2005). Zooplankton of turbid and hydrologically dynamic praire river, Freshwater Biology, 50 (9):1474-1491.

Vadadi-Fülöp, C.; Türei. D.; Sipkay, C.; Verasztó, C.; Drégelyi-Kiss, Á. and Hufnagel, L. (2009). Comparative assessment of climate change scenarios based on aquatic food web modeling. Environmental Modeling \& Assessment, 14: 563-576.

Vaidya, S. R. (2017). Biomonitoring of zooplankton to assess the quality of water in the nagpokhari of Kathmandu valley. International Journal of Zoology Studies, 2(1): 61-65.

Waller, W. T.; Dickson, K. L.; Atkinson, S. F. and Ammann, L. P. (2002). An analysis of phytoplankton abundance, zooplankton abundance and chlorophyll a data collected during the water quality surveys of Lake Texoma, 1999-2001 with comparison to 1996-1997 data. A report submitted for US Army Crops of Engineers, Tulsa District. 79pp.

Wang, C.; Xie, P. and Geng, H. (2010). The relative importance of physicochemical factors and crustaceanzooplankton as determinants of rotifer density and species distribution inlakes adjacent to the Yangtze River. Limnologica, 40 1-7.

Zakaria, H.Y. (2006). Zooplankton community in the Eastern Harbour of Alexandria, Egypt. The Egyptian Journal of Aquatic Research, 32 (Special Issue): 196-209.

Zakaria, H. Y. (2007). On the distribution of zooplankton assemblages in Abu Qir Bay, Alexandria, Egypt. The Egyptian Journal of Aquatic Research, 33 (1): 238-256.

Zakaria, H. Y. (2014). Impact of climate variability and anthropogenic activities on zooplankton community in the neritic waters of Alexandria, Egypt. Journal of King Abdul Aziz University, Marine Science, 25 (2).

Zakaria, H. Y. (2015). Article review: Lessepsian migration of zooplankton through Suez Canal and its impact on ecological system. The Egyptian Journal of Aquatic Research, 41(2): 129-144.

Zakaria, H. Y.; Hassan, A. M.; Abo-Senna, F. M.; El-Naggar, H. A. (2016). Abundance, distribution, diversity and zoogeography of epipelagic copepods off the Egyptian Coast (Mediterranean Sea). The Egyptian Journal of Aquatic Research 42 (4): 459-473.

Zakaria, H. Y.; Hassan, A. M.; El-Naggar, H. A. and Abo-Senna, F. M. (2018). Biomass determination based on the individual volume of the dominant copepod species in the Western Egyptian Mediterranean Coast. The Egyptian Journal of Aquatic Research 44: 89-99. 